\title{
TANTANGAN MENGAJAR PADA MASA PANDEMI COVID-19
}

\author{
Ridolf S.Th. Manggoa \\ Sekolah Tinggi Teologi Arastamar SETIA Ngabang \\ ridolfm@gmail.com
}

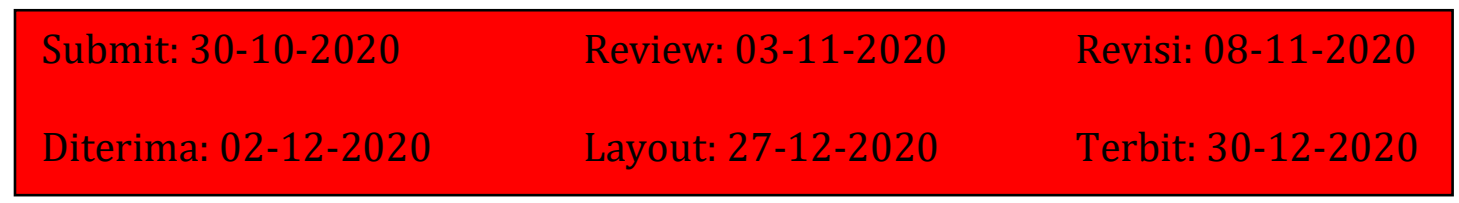

\begin{abstract}
This research was conducted to see and discover the teaching challenges associated with each teacher and lecturer when teaching in an atmosphere of the Covid-19 pandemic. This is important to research because there have been significant changes in teaching and learning activities when the massive spread of Covid-19 occurred. By using qualitative research based on literature review, some of the most striking challenges were obtained, namely: challenges from technology and instructional media, challenges of teacher unpreparedness, challenges of unsupportive facilities and infrastructure, methodological challenges, and human resource challenges. This research provides several solutions to minimize the impact caused by the above challenges, such as: teachers and lecturers must improve their competence in operating learning media and technology, teachers and lecturers must use the right method, and campuses or schools are required to support the teaching process. by providing facilities and infrastructure.
\end{abstract}

Keywords: Teaching, Covid-19, Challenges

\begin{abstract}
Abstrak
Penelitian ini dilakukan untuk mengetahui dan menemukan tantangan mengajar yang dihadapi oleh setiap guru dan dosen ketika mengajar dalam suasana pandemi covid-19. Hal ini penting untuk diteliti karena telah terjadi perubahan signifikan dalam kegiatan belajar-mengajar ketika penyebaran covid-19 semakin meluas. Dengan menggunakan penelitian kualitatif yang didasarkan pada kajian pustaka, maka diperoleh beberapa tantangan yang paling mencolok, yakni: tantangan dari teknologi dan media pembelajaran, tantangan ketidaksiapan guru, tantangan sarana dan prasarana yang kurang mendukung, tantangan metodologi, dan tantangan sumber daya manusia. Pada penelitian ini memberikan beberapa solusi untuk meminimalisir dampak yang ditimbulkan oleh tantangan-tantangan di atas, seperti: guru dan dosen harus meningkatkan kompetensi mengoperasikan media pembelajaran dan teknologi, guru dan dosen harus menggunakan metode yang tepat, dan kampus atau sekolah wajib mendukung proses kegiatan mengajar dengan menyediakan sarana dan prasarana.
\end{abstract}

Kata Kunci: Mengajar, Covid-19, Tantangan 


\section{Pendahuluan}

Penyebaran Covid-19 telah menjadi problem tersendiri di seluruh dunia, tidak terkecuali pada bidang pendidikan. Banyak Negara di dunia termasuk Indonesia telah mengalami resesi ekonomi sebagai dampak dari penyebaran pandemi Covid-19. Laporan WHO hingga 29 Agustus 2020 tercatat global 24.299.923 kasus konfirmasi, 827.730 kasus meninggal $(3,4 \%)$ angka kematian. Regional Asia Tenggara: 3.905 .060 kasus konfirmasi, 73.097 kasus meninggal $(1,9 \%) .{ }^{1}$

Data pertambahan kasus Covid-19 per 28 Agustus 2020 dilaporkan tercatat dari 33.082 spesimen yang diperiksa, hasilnya: 3.003 kasus positif (total 165.887), pasien sembuh bertambah 2.325 (total 120.900), dan meninggal dunia sebanyak 105 orang (total 7.169). Kasus ini merata di 486 kabupaten/kota di 34 provinsi dengan pertambahan yang paling tinggi di DKI: 869 dan Jabar: 526, sementara kasus suspek tercatat 77.857 orang. ${ }^{2}$ Upaya pencegahan penyebaran sudah dilakukan oleh pelbagai pihak terkait, antara lain Pedoman Pencegahan dan Pengendalian COVID-19 diterbitkan oleh Kemenkes RI per 20 Juli 2020 sebanyak 207 halaman bukan yang pertama karena edisi ini merupakan hasil revisi dari pedoman yang diterbitkan sebelumnya sebanyak 214 halaman pada 13 Juli 2020. Selain itu himbauan dipublikasikan seperti melalui hardcopy (buletin MasterPie) flyer animasi (Di Rumah Saja, Menjaga Jarak, dll) dan aplikasi (Germas; Hotline Covid-19 119 ext 9, Pikobar di Jawa Barat, CLM:corona.Jakarta.co.id, dll) baik oleh pemerintah maupun prakarsa masyarakat yang terus digaungkan untuk memberi penerangan tentang kondisi pandemi ini dan cara pencegahannya, misal gerakan dari binadesa.org untuk pembuatan antiseptik alami dari anggota SEPEDA di desa Galeso serta pelbagai gerakan serupa lainnya tersebar di seluruh nusantara. ${ }^{3}$

Khusus untuk bidang pendidikan, nyaris semua sekolah sekarang tidak dapat melakukan pembelajaran tatap muka. Berdasarkan surat Edaran Nomor 4 Tahun 2020 tentang Pelaksanaan Kebijakan Pendidikan dalam Masa Darurat Penyebaran Corona Virus Disease (Covid-19) yang diterbitkan oleh Menteri Pendidikan dan Kebudayaan Republik Indonesia bahwa proses pembelajaran dilakukan dengan menggunakan media daring (online). Artinya, proses belajar mengajar bagi peserta didik untuk sementara waktu dilakukan di rumah. Sejak terbitnya surat edaran tersebut tidak sedikit para guru khususnya guru agama Kristen mengalami kesulitan dalam mengoperasikan gawai dan laptop. Nadiah Ayu Wulandari mengatakan,

Untuk mengurangi angka penyebaran Covid-19 dan kegiatan pendidikan dapat berjalan seperti biasanya maka pemerintah melakukan beberapa upaya untuk mengurangi angka tersebut yang salah satunya diterapkan dalam sistem pendidikan di Indonesia. Pelaksanaan kegiatan belajar mengajar dilaksanakan

1 "Situasi Terkini Perkembangan Coronavirus Disease (COVID-19) 31 Oktober 2020," Kementerian Kesehatan RI., last modified 2020, https://covid19.kemkes.go.id/category/situasi-infeksi-emerging/info-coronavirus/\#.X56yI1MzbsF.

${ }^{2}$ Abdul Aziz, "Corona Indonesia 28 Agustus Bertambah 3.003: DKI 869, Jabar 526," Tirto.Id.

3 "Situasi Terkini Perkembangan Coronavirus Disease (COVID-19) 31 Oktober 2020." 
dengan sistem online atau sistem dalam jaringan (daring) sejak bulan Maret 2020. Sistem pembelajaran tersebut dilakukan tanpa tatap muka secara langsung, melainkan dilakukan dengan sistem pembelajaran jarak jauh. Dengan sistem pembelajaran jarak jauh, peserta didik tidak diharuskan atau diwajibkan untuk datang ke sekolah maupun kampus untuk melaksanakan pembelajaran. ${ }^{4}$

Artinya telah terjadi perubahan signifikan dalam proses mengajar selama terjadinya pandemi covid-19. Mulai dari strategi, metode hingga kompetensi. Di mana setiap guru atau pun dosen dituntut tidak hanya menguasai ilmu dari setiap pengetahuan yang diajarkannya kepada setiap siswa atau mahasiswa, namun mereka juga dituntut untuk dapat menguasai teknologi bahkan dapat mengoperasikannya.

Artinya ada penambahan tuntutan yang harus dan wajib dipenuhi oleh setiap guru dan dosen. Hal ini penting supaya dapat tercapai setiap tujuan dari pendidikan. Ferry Yang mengatakan, "Kata pendidikan yang dalam bahasa Inggris adalah education, berasal dari bahasa Latin educare, di mana ' $e$ ' adalah keluar, dan ducare adalah memimpin. Maka arti dari education atau pendidikan adalah memimpin keluar". ${ }^{5}$ Artinya, tujuan terlaksananya atau dilakukannya pendidikan adalah supaya setiap manusia dapat dipimpin dari kebodohan menuju terang ilmu pengetahuan. Sehingga diperlukan sebuah pendekatan, strategi hingga metode yang tepat sehingga dapat berjalan baik dan efektif, serta berdampak kepada perubahan signifikan pada siswa atau mahasiswa.

Sedangkan Syaiful Sagala memberikan penjelasan tentang pendidikan dengan mengatakan,

Pendidikan adalah proses yang tanpa akhir (education is the proses without end), dan pendidikan merupakan proses pembentukan kemampuan dasar yang fundamental baik menyangkut daya pikir daya intelektual maupun emosional perasaan yang diarahkan kepada tabiat manusia dan kepada sesamanya. Oleh karena itu, proses belajar menjadi kunci untuk keberhasilan pendidikan agar proses belajar menjadi berkualitas membutuhkan tata layanan yang berkualitas. ${ }^{6}$

Pendapat Syaiful di atas secara substansi tidak jauh berbeda dengan yang telah dikemukakan oleh Yang sebelumnya. Sekalipun dalam pendapatnya Syaiful menegaskan tentang tujuan pendidikan untuk pembentukan pengetahuan dasar berkaitan dengan intelektual, emosi hingga moral setiap individu. Bahkan baginya, pendidikan menjadi kunci keberhasilan seseorang.

Dengan demikian, dapat dikatakan pendidikan menjadi sangat urgen dalam pembangunan manusia yang seutuhnya. Di mana melaluinya, maka seseorang dapat bertransformasi menjadi individu yang yang berkualitas, tidak hanya secara intelektual, tetapi juga emosi dan spiritualnya.

${ }^{4}$ Nadiah Ayu Wulandari, "Dampak Pandemi Covid-19 Terhadap Pelaksanaan Pendidikan Di Indonesia," Https://Pustakabergerak.Id/, last modified 2020, https://pustakabergerak.id/artikel/dampak-pandemi-covid-19-terhadap-pelaksanaanpendidikan-di-indonesia- 2 .

5 Ferry Yang, Pendidikan Kristen (Surabaya: Momentum, 2018), hlm.3.

6 Wulandari, "Dampak Pandemi Covid-19 Terhadap Pelaksanaan Pendidikan Di Indonesia." 
Salah satu elemen penting dari pendidikan yang dapat dikatakan sebagai faktor penentu berhasil tidaknya sebuah pendidikan adalah kegiatan mengajarnya. Di mana kegiatan ini memegang peran yang kunci dan menjadi penentu setiap individu yang belajar untuk dapat berubah, berkembang atau mengalami tranfsormasi.

Akan tetapi justru dalam situasi covid-19 sekarang ini menunjukkan banyak tantangan yang dihadapi oleh kegiatan mengajar. Berdasarkan hasil penelitian yang dilakukan oleh Sahelatua mengatakan bahwa, ada beberapa kendala yang dialami oleh para guru yakni (1) Kurangnya pengetahuan guru tentang IT (2) Arus listrik di sekolah tidak normal serta internet tidak dapat memadai. ${ }^{7}$ Bahkan tantangan-tantangan yang muncul, apabila tidak dapat diantisipasi oleh setiap pendidik maka akan membuat setiap pengajaran bahkan metode mengajar mereka tidak akan berjalan dengan efektif dan berdampak signifikan bagi perubahan pada siswa dan mahasiswa. Tantangan-tantangan inilah yang akan diteliti dalam tulisan ini supaya dapat dikenali dan diberikan solusinya.

\section{Metode Penelitian}

Penelitian ini menggunakan metode kualitatif. Hal ini dilakukan untuk memperoleh data kualitatif yang valid dan faktual tentang topik yang dibahas dalam penelitian ini. Seperti yang dikemukakan oleh Yosia Belo, "Pendekatan ini diambil untuk memperoleh pemahaman kualitatif yang valid dan komprehensif bagi topik yang dibahas dalam penelitian ini". ${ }^{8}$ Ditambahkan oleh Adi Putra, "Semua kajian kualitatif di dalam penelitian ini bertumpu pada kajian literatur melalui sumber-sumber primer seperti buku, artikel jurnal, ensiklopedia dan majalah". ${ }^{9}$

Dengan demikian, melalui penelitian kualitatif yang dipilih oleh peneliti untuk meneliti topik ini, maka diharapkan peneliti dapat menyajikan data kualitatif yang valid guna sampai kepada kesimpulan dan hasil dengan penyajian data kualitatif yang juga dapat dipertanggungjawabkan.

\section{Pembahasan}

\section{Pengertian Mengajar}

Mengajar merupakan sebuah kemampuan yang wajib untuk dimiliki oleh setiap guru dan dosen, dan melalui ilmu yang dipelajari akan dapat menambah kemampuan dalam mengajar. Hal ini merupakan kemampuan dalam menghadapi siswa atau mahasiswa yang mereka semua memiliki karakter, kemampuan dan juga keinginan yang berbeda-beda.

Bagi kaum konstruktivis, mengajar bukanlah kegiatan memindahkan pengetahuan dari guru ke murid, melainkan suatu kegiatan yang memungkinkan siswa membangun sendiri pengetahuannya. Mengajar berarti partisipasi dengan pelajar dalam membentuk pengetahuan, membuat makna, mencari kejelasan, bersikap kritis, dan mengadakan justifikasi. Jadi, mengajar adalah suatu bentuk belajar sendiri. ${ }^{10}$

7 Mislinawati L. S. Sahelatua, L. Victoria, “'Kendala Guru Memanfaatkan Media IT dalam Pembelajaran di SDN 1 Pagar Air Aceh Besar,'” J. Chem. Inf. Model. 53, no. 9 (2017): 1689-1699.

8 Yosia Belo, "PENDIDIKAN AGAMA KRISTEN DALAM MATIUS 28:19-20," Jurnal LUXNOS 1, no. 2 (2020): 127-133.

${ }^{9}$ Adi Putra, “Kajian Biblika terhadap Makna 'Ta Stigmata Tou Iesou' Dalam Galatia 6: 17," SUNDERMANN: Jurnal Ilmiah Teologi, Pendidikan, Sains, Humaniora dan

Kebudayaan 13, no. 1 (2020): 1-12.

10 Paul Suparno, Psikologi Pendidikan: Suatu Pendekatan Baru (Yogyakarta: Kanisius, 1997)hlm. 65. 
Menurut Oemar Hamalik, mengajar memiliki beberapa definisi penting, di antaranya: a) Mengajar ialah menyampaikan pengetahuan kepada siswa didik atau murid di sekolah; b) Mengajar adalah mewariskan kebudayaan kepada generasi muda melalui lembaga pendidikan sekolah; c) Mengajar adalah usaha mengorganisasikan lingkungan, sehingga menciptakan kondisi belajar bagi siswa; d) Mengajar atau mendidik itu adalah memberikan bimbingan belajar kepada murid; e) Mengajar adalah kegiatan mempersiapkan siswa untuk menjadi warga Negara yang baik sesuai dengan tuntutan masyarakat; f) Mengajar adalah suatu proses membantu siswa menghadapi kehidupan masyarakat sehari-hari.11

Berdasarkan penjelasan Hamalik di atas, maka dapat diperoleh pemahaman bahwa mengajar merupakan kegiatan yang paling menentukan dalam terwujudnya tujuan dari pendidikan. Oleh karena melalui mengajar, guru atau dosen dapat menyampaikan pengetahuan, mewariskan kebudayaan, mengorganisasikan lingkungan, memberikan bimbingan belajar, memproduksi warga Negara yang baik dan membantu siswa atau mahasiswa menghadapi kehidupan praktis setiap hari.

Akan tetapi kegiatan ini bisa saja menjadi terhalangi, terkendala, dan berjalan tidak efektif karena dipengaruhi banyak faktor, apalagi pada masa sekarang, kondisi pandemi Covid-19 menjadi tantangan tersendiri dalam mengajar.

\section{Prinsip dan Tujuan Mengajar}

Setiap guru dan juga dosen perlu untuk memperhatikan kembali prinsip dan tujuan mengajar guna dapat menjadi acuan dan rujukan dalam mengajar. Sehingga senantiasa mengajar secara professional sekalipun dalam suasana pandemi covid-19.

Tadkir mengatakan, "Didaktik adalah ilmu mendidik anak yang memberikan prinsip-prinsip tentang cara-cara menyampaikan materi matematika pada khususnya sehingga dapat mudah dikuasai anak. Prinsip atau asas didaktik meliputi : asas apersepsi, peragaan, motivasi, belajar aktif, kerjasama, mandiri, penyesuaian dengan individu siswa, korelasi, dan evaluasi yang teratur". ${ }^{12}$

Selain prinsip yang telah dikemukakan di atas, masih ada beberapa prinsip mengajar yang perlu diperhatikan, yang diuraikan sebagai berikut:

Prinsip motivasi. Motivasi berpangkal dari kata "motif" yang dapat diartikan daya penggerak yang ada dalam diri seseorang untuk melakukan aktivitas-aktivitas tertentu demi tercapainya suatu tujuan, missal : Memberi angka, angka yang baik bagi mereka merupakan motivasi dalam kegiatan belajar.

Motivasi intrinsik disebut juga motivasi murni, karena muncul dari diri siswa sendiri : cara menjelaskan kaitan tujuan pembelajaran dengan kepentingan atau kebutuhan siswa missal : Kebutuhan untuk mewujudkan diri sendiri yakni mengembangkan bakat dengan usaha mencapai hasil dalam bidang pengetahuan, sosial, pembentukan pribadi. Motivasi ekstrinsik dapat dilakukan antara lain dengan cara memberi pujian, hadiah, menciptakan situasi belajar yang menyenangkan, memberi nasihat, atau upaya-upaya lain yang dapat membangkitkan semangat siswa dalam belajar. ${ }^{13}$

Prinsip Belajar Aktif. Belajar adalah menyangkut apa yang harus dikerjakan siswa untuk dirinya sendiri, maka inisiatif harus datang sendiri. Kegiatan fisik bisa berupa membaca, mendengar, menulis, berlatih keterampilan-keterampilan, dan sebagainya. Kegiatan psikis misalnya menggunakan khasanah pengetahuan yang dimiliki dalam

11 "Http://Digilib.Unila.Ac.Id/10522/24/BAB\%20II.Pdf" (n.d.).

12 Drs. Tadkir, "Prinsip - Prinsip Mengajar," Kompasiana.

13 Ibid. 
memecahkan masalah yang dihadapi, membandingkan satu konsep dengan yang lain, menyimpulkan hasil percobaan dan kegiatan psikis yang lain. ${ }^{14}$

Prinsip peragaan. Peragaan ialah suatu cara yang dilakukan oleh guru dengan maksud memberikan kejelasan secara realita terhadap pesan yang disampaikan sehingga dapat dimengerti dan dipahami oleh para siswa misalnya: meragakan pelajaran dengan perbuatan, percobaan-percobaan. ${ }^{15}$

Prinsip individualitas. Asas individualitas pada hakikatnya bukan lawan dari kooperasi. Asas ini dilatarbelakangi oleh perbedaan siswa baik dalam menerima, memahami, menghayati, menganalisis dan kecepatan mereka menerima pelajaran yang disampaikan oleh seorang guru misalnya: pengelompokan menurut kesanggupan, kelas dibagi beberapa kelompok dengan kesanggupan yang sama. ${ }^{16}$

Prinsip Mandiri. Dalam kegiatan belajar-mengajar, sedini mungkin dikembangkan kemandirian dalam belajar itu dengan menghindari campur tangan guru, namun guru selalu siap untuk ulur tangan apabila diperlukan, dalam belajar akan menempatkan guru dalam peran utama sebagai fasilitator dan motivator, di samping peran-peran lain: Informator, organisator, missal : pengembangan kemandirian dalam belajar di dalam bentuk-bentuk kegiatan terstruktur dan mandiri, atau kegiatan kokurikuler dan ekstrakurikuler. ${ }^{17}$

Prinsip kerjasama. Model pembelajaran kooperatif adalah konsep yang lebih luas meliputi semua jenis kerja kelompok termasuk bentuk-bentuk yang dipimpin oleh guru atau diarahkan oleh guru, missal : Kerja Kelompok, untuk memecahkan suatu problem, menganalisis masalah, pembagian tugas, kegiatan penyelidikan, dan kesimpulan. ${ }^{18}$

Prinsip apersepsi. Apersepsi berasal dari kata apperception, yang berarti menafsirkan buah pikiran, jadi menyatukan dan mengasimilasi suatu pengamatan berdasarkan pengalaman yang telah dimiliki dan dengan demikian memahami dan dapat menafsirkanya, missal : Sebelum pelajaran dimulai guru mencari titik tolak untuk menghubungkan pengetahuan yang telah dimiliki oleh siswa dengan cara mengajukan pertanyaan. ${ }^{19}$

Prinsip evaluasi. Yang dimaksud evaluasi di sini adalah penilaian guru terhadap proses kegiatan belajar-mengajar, contoh : Evaluasi tidak hanya dilaksanakan pada akhir semester saja tetapi setiap jam juga bisa karena akan berguna untuk mengetahui kemajuan hasil belajar. ${ }^{20}$

Prinsip korelasi. Maksudnya, peristiwa belajar mengajar adalah menyeluruh, mencakup berbagi dimensi yang kompleks, misalnya : dalam pembelajaran sudut sikusiku kita dapat menerangkan bahwa sangat penting kaitannya ilmu triple phytagoras dengan sudut siku-siku dalam ilmu bangunan. ${ }^{21}$

Setelah membahas tentang prinsip mengajar, maka selanjutnya perlu juga untuk membahasa tentang tujuan mengajar. Sekalipun prinsip dan tujuan mengajar tidak berdiri sendiri dan tidak terpisah karena keduanya akan berjalan bersama-sama. Akan tetapi penting dan perlu rasanya untuk membahas ini juga guna dapat diperhatikan oleh para guru dan dosen dalam mengajar, terutama di masa pandemi covid-19.
14 Ibid.
15 Ibid.
16 Ibid.
17 Ibid.
18 Ibid.
19 Ibid.
20 Ibid.
21 Ibid. 
Menurut Dr. Wina Sanjaya, M.Pd. (2007), tujuan belajar adalah kemampuan (kompetensi) atau keterampilan yang diharapkan dapat dimiliki oleh siswa setelah mereka melakukan proses pembelajaran tertentu. ${ }^{22} \mathrm{Hal}$ ini diperkuat oleh pendapat Dick dan Carey dengan mengatakan, "The Instructional goal statement that describes what it is student will be able to do after they have completed instruction". ${ }^{23}$

Tujuan belajar dan mengajar menurut Pupuh Fathurrahman \& M. Sobbry Sutikno, M.Pd (2007), merupakan suatu cita-cita yang bernilai normatif, terdapat sejumlah nilai yang harus ditanamkan kepada anak didik. Nilai-nilai tersebut akan mewarnai anak didik bersikap dan berbuat dalam lingkungan sosial, baik di sekolah maupun di luar sekolah. ${ }^{24}$

Mengajar merupakan suatu proses yang komplek, tidak hanya sekedar menyampaikan informasi dari guru kepada siswa. Mengajar juga tidak hanya sekedar memberikan materi sesuai dengan Rencana Pembelajaran, akan tetapi lebih jauh dari itu semua. Mengajar adalah usaha untuk menciptakan system lingkungan yang mengoptimalkan kegiatan belajar. Mengajar sebagai usaha menciptakan suasana belajar bagi siswa secara optimal. Mengajar berarti mengatur dan menciptakan kondisi yang terdapat di lingkungan siswa sehingga dapat menumbuhkan niat siswa melakukan kegiatan belajar. Penciptaan karakter anak didik adalah tugas utama dari pendidik..$^{25}$

Secara umum, mengajar adalah menyampaikan ilmu pengetahuan kepada anakanak didik di sekolah. Namun pada kenyataannya, pengertian mengajar lebih dari itu. Mengajar tidak hanya menyampaikan ilmu pengatuan, tetapi juga melatih pola piker anak-anak didik. Menurut Dr. Nana Sudjana, pengertian mengajar adalah membimbing siswa bagaimana belajar. Mengajar berarti mengatur dan menciptakan kondisi yang ada dilingkungan anak didik sehingga dapat melakukan kegiatan belajar. ${ }^{26}$

Secara sederhana, mengajar bertujuan untuk menyampaikan ilmu pengetahuan dan melatih pola pikir anak-anak didik. Dalam konteks pendidikan, ilmu pengetahuan dibagi menjadi dua bagian, yaitu ilmu eksak dan noneksak. Ilmu eksak adalah ilmu yang membutuhkan logika, perhitungan, dan daya analisis yang kuat, misalnya matematika, fisika, dan kimia. Ilmu eksak ini cenderung memaksimalkan kerja otak kiri. Sebaliknya, ilmu noneksak adalah ilmu yang membutuhkan teori, pemahaman, dan daya ingat yang kuat, misalnya ekonomi, seni, bahasa, dan sebagainya. Berbeda dengan ilmu eksak, kinerja otak kanan sangat dibutuhkan oleh ilmu noneksak ini. Sedangkan untuk tujuan melatih pola piker, seperti yang dikemukakan dalam bukunya yang berjudul "Taxonomy of Effective Teaching", Benjamin Bloom membagi pola pikir anak didik menjadi 5 tingkatan. Kelima tingkatan pola pikir tersebut adalah pengetahuan, pemahaman, penerapan, analisis, dan kreatif. ${ }^{27}$

Dengan demikian, berdasarkan beberapa pandangan yang telah dikutip di atas, memberikan sebuah pemahaman tentang tujuan mengajar yang tersentral kepada aktivitas yang berjalan dengan baik sehingga dapat efektif bagi setiap siswa dan mahasiswa yang belajar. Hasil apakah yang dimaksud? Hasil yang dimaksud di sini

22 “Tujuan Belajar Dan Mengajar," Manajemen Sekolah.

23 Ibid.

24 Ibid.

25 Tamrin Fathoni, “Tujuan Mengajar," SMART EDUCATION.

${ }^{26}$ Agus Sukirman, "Pengertian Mengajar dan Tujuannya," Pendidikanku, last modified 2013, http://sdnwonoue.blogspot.com/2013/09/pengertian-mengajar-dantujuannya.html.

27 Ibid. 
adalah terbentuknya karakter serta bertambahnya ilmu pada diri peserta didik guna menjadikan mereka manusia yang bermoral dan berilmu serta berakhlak.

\section{Tantangan Mengajar Pada Masa Pandemi Covid-19}

Berikut ini adalah tantangan-tantangan mengajar di masa pandemi covid-19:

\section{Tantangan dari Teknologi dan Media Pembelajaran}

Media dan teknologi pembelajaran menjadi begitu penting perannya dalam mengajar. Media dan teknologi pembelajaran merupakan elemen yang penentu dalam dunia pendidikan pada zaman sekarang. Itulah sebabnya, sejak beberapa dekade terakhir, guru dan dosen dituntut untuk dapat menguasai dan mampu mengoperasikan media dan teknologi pembelajaran. Seperti: mengoperasikan laptop untuk membuat presentasi dan mempresentasikan materi kuliah kepada mahasiswa melalui LCD dan tentunya dengan tampilan-tampilan yang juga harus menarik.

Tantangan ini juga dibenarkan oleh seorang Profesor dari Jerman. Guru besar University of Applied Science and Arts, Hannover, Germany and Senior Experten Services (SES) Germany, Prof. Dr. Gerhad Fortwengel, menyebutkan wabah corona ini justru menjadi katalis hebat yang memacu dunia pendidikan. Seperti mendorong lebih banyak pemanfaatan teknologi informasi dalam aktivitas pembelajaran jarak jauh. ${ }^{28}$

Pada masa pandemi covid-19, tuntutan itu akan semakin meningkat dan bertambah, di mana setiap pendidik dituntut tidak hanya dapat mengoperasikan laptop, LCD dengan presentasi yang menarik, namun mereka juga dituntut untuk dapat mengoperasikan beberapa aplikasi meeting online, aplikasi e-learning, hingga secara kreatif dapat mengatur kelasnya dengan absensi, metode penilaian yang juga online.

Menurut Muhammad Nadirudin Darul Haq, "Dibutuhkan kerja ekstra dari para guru untuk dapat menyampaikan materi pembelajaran pada masa darurat Covid-19 ini. PJJ online adalah jalan terbaik interaksi tanpa harus berhadapan dengan peserta didik di kelas,guru harus membentuk kelas virtual model mengajar dengan menggunakan beberapa aplikasi yang dikuasai oleh guru harus mulai mahir menggunakan aplikasi video Conference Zoom atau menggunakan Google Meet atau juga Webex VC Cisco.. Adalah keniscayaan jika seorang guru tidak mampu untuk menguasai berbagai aplikasi pembelajaran daring ini maka jangan harap PJJ ini akan berhasil". ${ }^{29}$

Menurut analisis dan pengamatan peneliti, hal ini merupakan tantangan tersendiri bagi kegiatan mengajar. Apabila guru atau dosen dapat mengalahkan dan dapat secara efektif mengajar secara online demi terciptanya tujuan pendidikan melalui kegiatan mengajar.

\section{Tantangan "Ketidaksiapan" Guru}

Apabila kondisinya normal seyogyanya guru siap dan siaga dalam mengajar. Kesiapan guru mengajar ditandai dengan membuat Silabus, RPS, RPP hingga materi ajar yang digunakan mengajar. Akan tetapi, kondisi normal seketika itu berubah untuk menyesuaikan kondisi di mana setiap guru dan dosen mengajar secara online, sehingga silabus, RPP, dan RPS yang seringkali digunakan, akhirnya harus diubah dan disesuaikan. Dalam hal ini termasuk juga materi mengajarnya juga harus disesuaikan supaya dapat dengan mudah diterima, dipahami dan diaplikasikan oleh setiap mahasiswa.

28 Ika, "Membedah Tantangan Pembelajaran Daring Di Tengah Pandemi Covid-19," Universitas Gadjah Mada, last modified 2020, https://ugm.ac.id/id/berita/19552membedah-tantangan-pembelajaran-daring-di-tengah-pandemi-covid-19.

29 Muhammad Nadirudin Darul Haq, "Tantangan Mengajar Online Masa Pandemi Covid-19," Kabar Priangan (Bandung, Jawa Barat, 2020). 
Sekali lagi, dalam hal ini apabila guru atau dosen tidak siap maka pasti kegiatan mengajar tidak akan berjalan dengan baik dan efektif. Itulah sebabnya, dalam penelitian ini, ditempatkan pada tantangan mengajar kedua. Supaya dapat diantisipasi demi terciptanya kegiatan mengajar yang dapat mentransformasi siswa atau juga mahasiswa.

\section{Tantangan Sarana dan Prasarana Mengajar yang Kurang}

Pada masa pandemi sekarang ini, banyak guru, dosen hingga siswa dan mahasiswa yang mengeluhkan jaringan atau sinyal internet yang seringkali mengganggu kegiatan belajar online. Oleh karena harus diakui bahwa di bangsa ini, jaringan internet masih perlu ditingkatkan dan diperluas jangkauannya. Makanya jangan heran ada banyak pemberitaan tentang siswa yang tidak bisa belajar karena di rumahnya tidak mendapat jaringan internet.

Selain itu, meskipun ada jaringan internet, namun seringkali mahasiswa atau siswa justru diperhadapkan dengan masalah tidak tersedianya Smartphone dan laptop yang digunakan untuk belajar online. Ulfa Hikmat mengatakan, "Tantangan yang paling umum dalam pelaksanaan pembelajaran daring ini adalah kurangnya pemahaman guru dan siswa dalam penggunaan teknologi dan terbatasnya akses jaringan internet. Padahal hal ini merupakan bagian terpenting untuk menjalankan sistem pembelajaran daring ini. Hal ini menjadi salah satu kendala dan tantangan besar yang harus dihadapi, dalam keterbatasan ini menyebabkan proses belajar mengajar dengan sistem pembelajaran daring ini tidak optimal dan hasil yang didapat pun tidak sesuai dengan yang diharapkan". ${ }^{30}$ Fenomena tersebut, menurut Teddy Tryadi Nugroho, dikarenakan ketersediaan infrastruktur digital yang belum merata, Indonesia saat ini belum menyediakan infrastruktur Teknologi Informasi dan Komunikasi (TIK), prasyarat utama untuk pembelajaran jarak jauh, yang memadai dan meluas untuk seluruh warganya". ${ }^{31}$

Dengan demikian dapat dilihat betapa sarana dan prasarana menjadi sangat menentukan efektif-tidaknya aktivitas mengajar yang dikerjakan oleh guru atau dosen. Itulah sebabnya apabila pihak kampus atau sekolah tidak menyediakan fasilitas yang mendukung kegiatan mengajar online, maka akan sangat berdampak signifikan kepada kegiatan tersebut. Dalam hal ini, dampaknya pasti akan cenderung negatif.

\section{Tantangan Penggunaan Metodologi}

Tantangan ini bisa saja memiliki hubungan dengan tantangan ketidaksiapan guru atau dosen. Sekalipun sebenarnya, poin ini secara spesifik atau dengan skop yang lebih sempit hanya menyoroti metodologinya. Bagian ini mencakup cara mengajarnya, cara menilai dan cara memberikan evaluasi kepada mahasiswa dan siswa. Hal ini dibenarkan oleh Dekan Fakultas Farmasi UGM, Prof. Dr. apt. Agung Endro Nugroho dengan berkata, "Di era revolusi industri 4.0, dunia pendidikan tinggi termasuk farmasi menghadapi tantangan dengan berbagai perubahan yang ada. Ditambah adanya pandemi Covid-19 menuntut pendidikan tinggi untuk bisa melakukan penyesuaian dalam penyelenggaraan pendidikan. Salah satunya mengubah metode pembelajaran tatap muka (luring) menjadi daring saat pandemi". ${ }^{32}$

30 Ulfa Hikmah, “Tantangan Pembelajaran Daring Ditengah Pandemi Covid-19," Kumparan, last modified 2020, https://kumparan.com/ulfa-hikmah/tantanganpembelajaran-daring-ditengah-pandemi-covid-19-1tyWr4BZkCe/full.

31 Teddy Tryadi Nugroho, "Pembelajaran Jarak Jauh Di Masa Pandemi," Tempo.Co.

32 Ika, "Membedah Tantangan Pembelajaran Daring Di Tengah Pandemi Covid-19." 
Berdasarkan kutipan di atas, penggunaan metodologi perlu mewakili dan merefleksikan kemampuan siswa atau mahasiswa usai mengikuti pembelajaran online. Hal ini patut disoroti karena kondisi mengajar online pada masa pandemi covid-19 adalah kondisi yang baru. Mayoritas guru dan dosen tidak terbiasa dengan situasi ini. Tidak menutup kemungkinan ada guru dan dosen yang tetap menerapkan metodologi yang sama dalam mengajar online dengan mengajar konvensional. Hal ini dapat berpotensi menjadikan kegiatan mengajar tidak berjalan dengan baik dan efektif.

\section{Tantangan dari SDM}

Yang dimaksud dengan tantangan dari SDM adalah lebih spesifik kepada konteks siswa atau mahasiswa yang belajar, terutama tingkat kemampuan siswa dan mahasiswa untuk memahami materi belajar, mengoperasikan alat-alat teknologi informasi yang digunakan hingga aplikasi-aplikasi belajar daring.

Selain itu, siswa dan mahasiswa juga perlu beradaptasi cara belajar dan mengajar dosen dan guru secara online. Berbagai kesulitan dalam memahami materi kuliah dapat terjadi.

Masih ada satu masalah klasik yang menjadi penghambat terlaksanakan pembelajaran online di Negara Indonesia. Ali Sadikin dan Afreni Hamidah juga menyatakan hal yang sama. Itu terlihat jelas dalam pernyataan mereka bahwa, "Lebih lanjut, tantangan pembelajaran daring adalah ketersediaan layanan internet. Sebagian mahasiswa mengakses internet menggunakan layanan selular, dan sebagian kecil menggunakan layanan WiFi. Ketika kebijakan pembelajaran daring diterapkan di Universitas Jambi, mahasiswa pulang kampung. Mereka mengalami kesulitan sinyal selular ketika di daerah masing-masing, jikapun ada sinyal yang didapatkan sangat lemah". 33

Dengan demikian, penyediaan jaringan internet yang menyeluruh dan menjangkau setiap pelosok di tanah air ini harus juga menjadi perhatian pemerintah. Akan tetapi, sekali lagi hal ini juga kembali lagi kepada SDM yang memadai. Itulah sebabnya, hal ini pun dijadikan sebagai salah satu tantangan dalam pembelajaran online pada masa pandemi ini.

\section{Solusi yang Ditawarkan}

Berikut ini dikemukakan beberapa solusi yang ditawarkan demi meminimalisir dampak negatif yang ditimbulkan oleh tantangan-tantangan di atas apabila tidak dapat diantisipasi.

\section{Guru dan Dosen Perlu Meningkatkan Kemampuan Mengoperasikan Media dan Teknologi Pembelajaran}

Guru dan dosen perlu menguasai dan meningkatkan kemampuan dalam mengoperasikan serta menggunakan aplikasi belajar online... Dampak pandemi Covid19, sebagaimana yang diamati Rina Savina, bahwa kondisi ${ }^{34}$ inilah yang semakin menuntut semua golongan masyarakat untuk tidak gagap teknologi, khususnya para guru". ${ }^{35}$

Dalam meminimalisir dampak negatif dari tantangan yang dihadapi oleh para guru dan dosen, tindakan untuk meningkatkan kompetensi dalam mempergunakan atau

33 Afreni Hamidah Ali Sadikin, "Pembelajaran Daring Di Tengah Wabah Covid-19,"

Biodik: Jurnal Ilmiah Penelitian Biologi Vol. 6, no. No. 2 (2020): 214-224.

34 Rina Savina, "Masa Pandemi Covid-19 Mengharuskan Guru Tidak Gaptek," Kompasiana.

35 Ibid. 
mengoperasikan media dan teknologi guna mendukung terciptanya proses belajar mengajar yang efektif, adalah tindakan yang tepat.

\section{Guru dan Dosen Perlu Menggunakan Metode mengajar yang tepat}

Keberhasilan kegiatan mengajar juga sangat ditentukan oleh pemilihan dan penggunaan metode mengajar yang tepat. Guru dan dosen perlu menerapkannya. Dalam hal ini, perlu juga mempertimbangkan karakteristik setiap mahasiswa yang mengajar, mata pelajaran yang diampu dan media pembelajaran yang digunakan.

Sevima.com menulis tentang tujuh (7) tips mengajar dari Mendikbud pada masa pandemi covid-19 seperti yang dikemukakan oleh Nadim Makarim ketika memperingati Hari Pendidikan Nasional pada tanggal 2 Mei yang lalu: (1) Jangan Stess, (2) Mencoba untuk membagi kelompok belajar menjadi kelompok kecil-kecil; (3) Mencoba untuk project based learning; (4) Alokasikan waktu lebih banyak waktu bagi yang tertinggal; (5) Fokus terhadap waktu yang paling penting; (6) Saling interaksi dengan sesama guru; dan (7) Have fun. ${ }^{36}$

Berdasarkan tips dari Menteri Pendidikan di atas, maka ada tiga (3) di antaranya yang berkaitan dengan penggunaan metode yang tepat: tips nomor 2 tentang membuat kelompok belajar yang lebih kecil, tips nomor 3 tentang mencoba project based learning, dan tips nomor 7 tentang bagaimana pembelajaran dibuat atau didesain sehingga lebih fun.

Pada masa pandemi covid-19 penting bagi guru dan dosen untuk mengajar dengan fokus kepada kelompok yang lebih kecil. Biasanya, melakukan penyampaian materi terhadap siswa dilakukan di dalam kelas. Satu guru bertugas untuk menerangkan secara langsung tentang semua materi di depan kelas. Namun, di tengah wabah seperti ini, kegiatan tersebut harus dihentikan. Untuk mengganti cara tersebut para pengajar bisa melakukan pengajaran dengan sistem kelompok kecil, sehingga dapat membuat sistem belajar mengajar lebih efektif. Selain itu, belajar dalam sistem kelompok kecil juga dapat mengantisipasi kemampuan siswa yang tidak sama.

Selanjutnya pada masa pandemi covid-19 seperti sekarang ini, perlu juga bagi guru dan dosen untuk mencoba project based learning. Maksudnya, Group project assignment diharapkan para peserta mampu bertanggung jawab tentang tantangan dan kolaborasi mereka untuk bertanggung jawab terhadap tugas mereka. Siswa mampu mengampu apa yang sudah menjadi tugas mereka dan dapat terealisasikan dengan baik. Dalam sistem project based learning ini bisa dikaitkan dengan pembagian kelompok kecil. Sehingga siswa mampu bekerja sama dengan teman satu kelompoknya. Harapanya, dengan melakukan pembagian kelompok kecil ini siswa juga dapat termotivasi dari teman-temannya yang lain.

Terakhir, setiap guru dan dosen juga perlu untuk senantiasa have fun saat mengajar sekalipun secara online.. Ciptakan pembelajaran yang menyenangkan ; penyampaian materi yang dilakukan secara efektif, dapat memiliki pengaruh bagi terciptanya pembelajaran sebagaimana yang diharapkan berdasarkan tujuan pembelajaran itu sendiri.

\section{Sekolah dan Kampus Perlu menyediakan fasilitas kuliah online}

36 “Penting! Ini 7 Tips Mengajar Dari Mendikbud Di Masa Pandemi Covid-19," Sevima. 
Pihak kampus atau sekolah perlu mempersiapkan fasilitas yang memadai guna terciptanya pembelajaran yang baik, seperti jaringan internet, bantuan pulsa atau kuota, hinga alat atau media pembelajaran.

Teddy Tryadi Nugroho menambahkan, "Terlepas dari hal itu kesiapan dan tantangan dalam Pembelajaran Jarak Jauh sangat penting guna menghidupkan kembali semangat Tridharma perguruan tinggi di masa pandemi ini. Untuk itu berbagai macam persoalan mengenai Perubahan metode tatap muka di kelas menjadi termediasi via layar laptop membutuhkan adaptasi dan perubahan yang harus di evaluasi. Terutama dari sisi penyiapan materi dan interaksi dalam ruang digital. Persoalan pemerataan akses informasi juga harus diperhatikan oleh perguruan tinggi terkait. Hal ini berguna agar tidak adanya kesenjangan sosial di antara mahasiswa". ${ }^{37}$

\section{Kesimpulan}

Berdasarkan penjelaskan di atas, dapat disimpulkan bahwa tantangan mengajar dalam situasi pandemi covid-19 telah dirasakan oleh para guru dan dosen di berbagai sekolah dan perguruan tinggi. Penanganan serius dan keterlibatan guru dan dosen dalam meningkatkan proses PJJ, memberikan pengaruh yang signifikan bagi terjudunya nilai-nilai pendidikan dan hasil dari proses pembelajaran dimaksud.

Tantangan yang muncul di masa pandemi covid-19 seperti tantangan dari teknologi dan media pembelajaran, ketidaksiapan guru dan dosen dalam mengajar, sarana dan prasarana yang kurang memadai, pemilihan metodologi, dan kuranganya SDM, berdampak pada proses PJJ, sehingga dibutuhkan solusi seperti: guru dan dosen perlu meningkatkan kemampuan dan keterampilan mengoperasikan teknologi dan media pembelajaran secara daring, guru dan dosen perlu memilih dan menggunakan metode mengajar yang tepat, dan pihak kampus atau sekolah perlu memberikan fasilitas kepada setiap guru atau dosen bahkan termasuk mahasiswa guna terciptanya kegiatan mengajar yang lebih kondusif dan efektif. 


\section{Referensi}

Adi Putra. "Kajian Biblika Terhadap Makna 'Ta Stigmata Tou Iesou’ Dalam Galatia 6: 17." SUNDERMANN: Jurnal Ilmiah Teologi, Pendidikan, Sains, Humaniora Dan Kebudayaan 13, no. 1 (2020): 1-12.

Ali Sadikin, Afreni Hamidah. "Pembelajaran Daring Di Tengah Wabah Covid-19." Biodik: Jurnal Ilmiah Penelitian Biologi Vol. 6, no. No. 2 (2020): 214-224.

Aziz, Abdul. “Corona Indonesia 28 Agustus Bertambah 3.003: DKI 869, Jabar 526.” Tirto.Id.

Belo, Yosia. "PENDIDIKAN AGAMA KRISTEN DALAM MATIUS 28: 19-20." Jurnal LUXNOS 1, no. 2 (2020): 127-133.

Hikmah, Ulfa. “Tantangan Pembelajaran Daring Ditengah Pandemi Covid-19.” Kumparan. Last modified 2020. https://kumparan.com/ulfa-hikmah/tantanganpembelajaran-daring-ditengah-pandemi-covid-19-1tyWr4BZkCe/full.

Ika. "Membedah Tantangan Pembelajaran Daring Di Tengah Pandemi Covid-19." Universitas Gadjah Mada. Last modified 2020. https://ugm.ac.id/id/berita/19552membedah-tantangan-pembelajaran-daring-di-tengah-pandemi-covid-19.

L. S. Sahelatua, L. Victoria, Mislinawati. “'Kendala Guru Memanfaatkan Media It Dalam Pembelajaran Di Sdn 1 Pagar Air Aceh Besar.'” J. Chem. Inf. Model. 53, no. 9 (2017): 1689-1699.

Nadirudin Darul Haq, Muhammad. "Tantangan Mengajar Online Masa Pandemi Covid19.” Kabar Priangan. Bandung, Jawa Barat, 2020.

Nugroho, Teddy Tryadi. "Pembelajaran Jarak Jauh Di Masa Pandemi." Tempo.Co. Savina, Rina. "Masa Pandemi Covid-19 Mengharuskan Guru Tidak Gaptek." Kompasiana. Sukirman, Agus. "Pengertian Mengajar Dan Tujuannya." Pendidikanku. Last modified 2013. http://sdnwonoue.blogspot.com/2013/09/pengertian-mengajar-dantujuannya.html.

Suparno, Paul. Psikologi Pendidikan: Suatu Pendekatan Baru. Yogyakarta: Kanisius, 1997. Tadkir, Drs. "Prinsip - Prinsip Mengajar." Kompasiana.

Tamrin Fathoni. "Tujuan Mengajar." SMART EDUCATION.

Wulandari, Nadiah Ayu. "Dampak Pandemi Covid-19 Terhadap Pelaksanaan Pendidikan Di Indonesia." Https://Pustakabergerak.Id/. Last modified 2020.

https://pustakabergerak.id/artikel/dampak-pandemi-covid-19-terhadappelaksanaan-pendidikan-di-indonesia-2.

Yang, Ferry. Pendidikan Kristen. Surabaya: Momentum, 2018.

"Http://Digilib.Unila.Ac.Id/10522/24/BAB\%20II.Pdf" (n.d.).

"Penting! Ini 7 Tips Mengajar Dari Mendikbud Di Masa Pandemi Covid-19." Sevima.

"Situasi Terkini Perkembangan Coronavirus Disease (COVID-19) 31 Oktober 2020." Kementerian Kesehatan RI. Last modified 2020.

https://covid19.kemkes.go.id/category/situasi-infeksi-emerging/info-coronavirus/\#.X56yI1MzbsF.

“Tujuan Belajar Dan Mengajar." Manajemen Sekolah. 